\section{Theoretical \& Applied Science}

p-ISSN: 2308-4944 (print) e-ISSN: 2409-0085 (online)

Year: 2015 Issue: 07 Volume: 27

Published: $30.07 .2015 \quad$ http://T-Science.org
Ilhom Tairov

Senior research scientist Assistant of the department "Philosophy" The Fergana State University, Uzbekistan conference_2012@list.ru

SECTION 30. Philosophy.

\title{
INTERACTION OF CIVILIZATIONS AND INTER-CIVILIZATIONAL APPROACH TO THE DEVELOPMENT OF SOCIETY FROM THE STANDPOINTS OF THE CIVILIOGRAPHY
}

\begin{abstract}
In this article the interaction and relationships of modern world civilizations within the framework of inter-civilizational approach to the development of society are considered.. In modern conditions it is necessary to speak about the further deepening of scientific knowledge in the field of young science - civiliography. From the perspective of civiliography in the context of globalization it is possible to consider the prospects of development of world civilization in general, taking into account conflicts and their peaceful resolution.

Key words: civilization, inter-civilizational approach, civiliography, globalization, local civilization, Western civilization, complementarity.

Language: English

Citation: Tairov I (2015) INTERACTION OF CIVILIZATIONS AND INTER-CIVILIZATIONAL APPROACH TO THE DEVELOPMENT OF SOCIETY FROM THE STANDPOINTS OF THE CIVILIOGRAPHY. ISJ Theoretical \& Applied Science 07 (27): 180-182.

Soi: http://s-o-i.org/1.1/TAS-07-27-32 Doi: crossef http://dx.doi.org/10.15863/TAS.2015.07.27.32
\end{abstract}

The problem of interaction of civilizations in the modern era is one of the sharpest socialphilosophical problems. Despite the differences in approaches to the classification of types of civilizations, all researchers acknowledge the existence of different, often diametrically opposite to each other, civilizations. The modern world is a multicultural and multi-ethnic formation, where every culture and every nation takes its place in the general system of world culture.

However, as never before, there is a desire for unification and domination of certain civilizations over others. These aspirations are opposed to the pursuit of localization, regionalism, and sometimes isolation. If in previous eras of the Western civilization was identified with the Christian world and was understood as a region of the Western Europe, world-system which was the successor of the Roman Empire, with the advent of new, powerful Empire - the United States of America, the status of the Western civilization has undergone dramatic changes.

Now the Western civilization has become the most powerful and influential force on the world stage for economic coverage and ideological influence. This is manifested in the global influence of the strongest western economically developed countries and the total spread of the western lifestyle (including the creation of political institutions and the formation of a system of moral values).

In the context of globalization, there is a gradual weakening of the sovereignty of many countries, and, as a consequence, the erosion of national identity. Socio-economic processes taking place in modern civilization can no longer be considered domestic or regional. World, on the one hand, strives for unity, but on the other hand, every nation strives to preserve the originality.

Interest in the problem of prospects of development of civiliography continues to grow. An important role here is played by globalization, its multidimensional, contradictory consequences, the debate on new terms and types of civilization development (in particular, ambiguous perception of concepts about "unification" of cultures or, on the contrary, is about strengthening asymmetric, unequal in their situation), increased an attention to certain aspects of the "crisis of identity", etc [2].

Impact also serious geopolitical shifts, the increasing role of new "centers of power" in the world economy and international relations, the emergence in this context, new configurations and conflicts. 
It can be foreseen that the importance of innovative breakthrough strategies, comparisons of their various models in the context of development of "civilization of knowledge" will increase more and more. In such circumstances, expanding the international debate on a number of questions and inevitably intensify disputes.

First of all, this recognition of the thesis of the diversity of world civilizations. Moreover, in the words of most politicians and researchers declares the equality of all civilized communities (including, for example, western, Chinese, Muslim, orthodox, etc.).

However, the reality shows that some of them are based on the idea of being "chosen ones and secondarily, "subordination" of other civilizations, reject multicivilizational approach, recognizing the progressive role of primarily Western civilization [4, 7], and its separate subcivilizations.

This happens often on the background of divergent judgments about the nature and classification of civilizations, the importance of certain aspects and factors of their development.

For example is still some debate about the relationship between the concepts of "culture" and "civilization". From the point of view of some civiligraphers, these concepts are close; they are, in fact, complement each other. Other authors, on the contrary, its sharply oppose, "colliding" with each other. And in civilization rather see, basically, violence, aggressiveness, etc. These include, for example, some German followers, N. Elias and other modern philosophers [5].

Differences occur in terms of the typological approach to the assessment of civilizations. They are based on different indicators. After all, the most frequently civilizations are divided according to the spatial indicators, and taking into account shifts in geopolitics, the nature of the economic and stadialformational structures, the uniqueness of societal and social characteristics, the characteristics of the collective mentality, intellectual and spiritual culture, values and attitudes.

Different researchers of civilizations often come to ambiguous conclusions. So, some pay a special, even priority the degree of "democracy", the others - on the contrary, the level of "despotism" and authoritativeness of certain societies.

The majority of researchers, studying the driving forces of civilization development, proceed from the priority of a multifactorial approach to the history of civilizations. For them, the decisive factor is the totality of factors. A large focus of the material, socio-economic factors. In turn, some of their opponents are focused mainly on the "riser" processes and institutions, on the cultural and historical side of things.

The essence of the inter-civilizational interaction is to search for a new type of the integrity of the global socio-cultural space based on the balance between natural and historically, economically and culturally appropriate forms of development for countries of different national and cultural specificity.

The specificity of inter-civilizational interaction in the era of globalization is a critical understanding of the universality of globalization transformations and the awareness of the need to preserve national and cultural identity of individual nations and countries. The problem of national and cultural identity is dictated by the need to preserve national sovereignty and determine the path of development of the country as an equal subject of the world community.

Ethnic and interethnic conflicts presented as a conflict of civilizations, in fact, is a reflection of the continued social injustice and inequality of opportunities in today's global society.

The emergence of the concept of the "clash of civilizations" is connected with growing backlash against globalization, held in the interests of western countries. The growing tensions in intercivilizational relations has the following sources: a) the systemic crisis of western liberal democracy; b) the desire of some countries to maintain world domination; c) fear of competition rapidly developing countries of eastern civilization; d) increasing the activity of the Islamic world and its reaction to the global dictates of some countries.

Civilizational differences should be seen not as a source of conflict, but as a factor of development and enrichment, as a manifestation of the complementarity of different civilization types. The concept of "significant other" should form the basis of a new perception of different civilizational entity [6].

The formation of a new type of national and cultural identity of modern civilization is possible only under condition of creation of civil society. It should be based on "equality of starting conditions and opportunities, objective and fair the difference in income, the elimination for all the degrading poverty and lack of minimum social benefits.

The basis of the national idea of any state must be based on the concept of social justice. The implementation of this concept implies a radical improvement in the lives of people, ending social discrimination, providing social guarantees to all categories of population, equality of initial opportunities, the formation of a legitimate state authority and civil liability ruling elites.

Prospects of the relations between civilizations in the unity of the fate of mankind. A new system of relations can be built only on the principles of cooperation, compromise, tolerance, communication on the basis of the values of freedom, equality, solidarity and social justice [13]. 


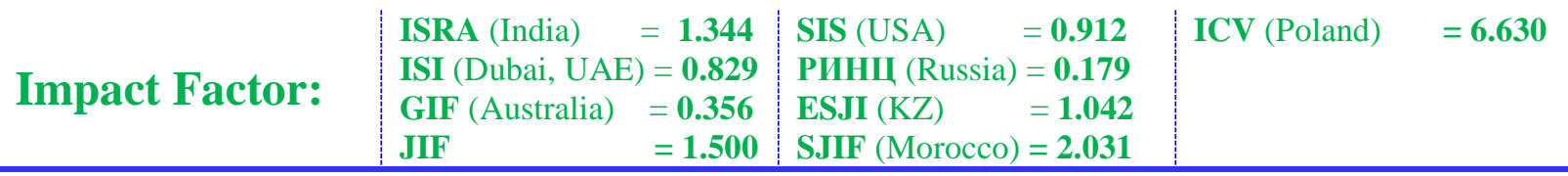

\section{References:}

1. Brodel' Fernan (2008) Grammatika civilizacij. Moscow: Ves' mir, 2008.

2. Chernjak EB (2006) Civiliografija. Nauka o civilizacii. Moscow: Mezhdunarodnye otnoshenija, 2006.

3. Jakovec JV (1997) Istorija civilizacij. 2-e izd. Uchebnoe posobie. Moscow: Vlados, 1997 (Vvedenie. Gl. 1.)

4. Timofeev $\mathrm{T}$ (2007) Civilizacii i mirovoe razvitie. - V kn. «Rossija v mnogoobrazii civilizacij». Pod red. N. Shmeleva, T. Timofeeva, V. Fedorova. (Chast' I, gl. pervaja «Civilizacii i sovremennoe miroustrojstvo». IE RAN. Moscow, 2007, pp. 27-42).

5. Kuzyk BN, Jakovec JV (2006) «Civilizacii: teorija, istorija, dialog, budushhee». V dvuh tomah. Moscow, 2006.

6. (2004) «Sintez - civilizacii i kul'tury». Mezhd. Al'manah. Moscow. RAN., 2003, 2004.

7. Timofeev T (2004) «Civilizacionnye protivorechija i obshhestvennaja mysl'. (K internacional'nym debatam)». Moscow, «Ogni», 2004. 103 p.

8. (2008) «Mir civilizacij $\mathrm{V}$ nastojashhem i budushhem». Sb. dokladov k mezhdunarodnomu civilizacionnomu forumu. MISK. Moscow, 2008.

9. Erasov B (2002) «Civilizacii: universalii i samobytnost'» (Moscow, «Nauka», 2002).

10. (2006) «Skol'ko na Zemle civilizacij?» // V zhurn. «Rossija v global'noj politike». (№ 5, 2006), «Ne stolknovenie, a partnerstvo» (№ 6, 2007).

11. (2005) «Dialog civilizacij. Povestka dnja». IF RAN i Gorbachev - Fond, Moscow, 2005.

12. Tolstyh V (2005) Budushhee civilizacii V kontekste dialoga kul'tur / «Dialog kul'tur v globalizirujushhem mire». Moscow, Nauka, 2005, pp. 151-169.

13. (2008) «Prognozirovanie budushhego: novaja paradigma». (gl. I, V). Moscow, «Jekonomika», 2008. 